\title{
Inflammation and Carcinogenesis
}

\author{
Yu-Sheng Wu, Shiu-Nan Chen*
}

Department of Life Science, National Taiwan University, Taipei, Taiwan

Email: *snchen@ntu.edu.tw

Received November $6^{\text {th }}, 2013$; revised November $26^{\text {th }}$, 2013; accepted December $3^{\text {rd }}, 2013$

Copyright (C) 2013 Yu-Sheng Wu, Shiu-Nan Chen. This is an open access article distributed under the Creative Commons Attribution License, which permits unrestricted use, distribution, and reproduction in any medium, provided the original work is properly cited. In accordance of the Creative Commons Attribution License all Copyrights (C) 2013 are reserved for SCIRP and the owner of the intellectual property Yu-Sheng Wu, Shiu-Nan Chen. All Copyright (C) 2013 are guarded by law and by SCIRP as a guardian.

\begin{abstract}
We consider that inflammatory substances play an important role in the carcinogenesis process. In the process, cytokines and growth factor secreted by cells can actively recruit immune cells in the carcinogenesis microenvironment, further, promote carcinogenesis progression. The carcinogenesis microenvironment even subverted the immune system, moreover, enhanced the carcinogenesis through immune suppressive mechanisms within the carcinogenesis microenvironment.
\end{abstract}

Keywords: Inflammation; Carcinogenesis; Microenvironment

\section{Introduction}

Inflammation is known to be a crucial adaptive response for animals, and the mechanism is a complex interaction with molecular mediators even the functions of immune cells in a microenvironment through a response that occurs at all levels of biological organization [1]. In this process, cooperation among cells and mediators occurs, and a wide range of factors are involved in the classical immune response, including 1) the stage of the inflammation process; 2) the tissue or organ involved; and 3) whether the inflammation is acute and resolving or chronic and non-resolving [2]. The inflammation process involves vascular permeability, active migration of blood cells, and the passage of plasma constituents into injurious tissue [3]. Through the infiltration of immune cells, studies have shown that the inflammation process plays a crucial role in atherosclerosis [4]. Blood leukocytes, mediators of host defenses and inflammation, localize in the earliest lesions of atherosclerosis in experimental animals. The study of inflammation in atherosclerosis has afforded considerable new insights into the mechanisms underlying the recruitment of leukocytes [5]. Recently, studies have indicated the role of inflammation in Alzheimer disease (AD) [6]. Inflammatory components related to AD neuroinflammation include brain cells, such as microglia and astrocytes, the complement system, and

${ }^{*}$ Corresponding author. cytokines and chemokines [7]. Regarding cancer development [8], pro-inflammatory cytokines, including interleukin (IL)-1 $\alpha$, IL-1 $\beta$, IL-6, IL-8, IL-18, chemokines, matrix metallopeptidase (MMP)-9, and vascular endothelial growth factor (VEGF) are primarily regulated by the transcription factor nuclear factor (NF)-kB, which is active in most tumors and is induced by carcinogens [9].

\section{Mediators of Inflammation}

Studies have investigated the cytokines involved in the inflammation response by using various animal models. The expression of pro-inflammatory cytokines, such as tumor necrosis factor alpha (TNF)- $\alpha$, is significantly increased in the adipocytes of obese animals (ob/ob mouse, $\mathrm{db} / \mathrm{db}$ mouse, and fa/fa Zucker rat) [10]. The activation of TNF- $\alpha$ might induce leukocytes express adhesion molecules on the cell surface [11], leading to diapedesis through individual vascular endothelial cells [12]. IL-6 is an adipokine [13] thought to be a mediator of anti-inflammation [14] that is produced by adipose tissue and liver-resident macrophages that are activated in response to hepatocyte death [15]. IL-6-deficient mice exhibit a marked decrease in inflammatory response, granulation tissue formation, and re-epithelialization [16]. The IL-1 family, which includes IL- $1 \alpha$ and IL- $1 \beta$, exhibits strong pro-inflammatory activities and plays a major role in host responses to exogenous and endogenous noxious stimuli 
[17]. IL 1 induces the expression of adhesion molecules on endothelial cells and elicits stromal cells to release chemokines that promote the recruitment of inflammatory cells at the inflammation site [18]. Such inflammation occurs significantly in cases of comorbidity and might contribute to the increased risk of developing cardiovascular accidents observed in these patients [19]. IL-10, a cytokine with anti-inflammatory properties, plays a central role in infection that involves limiting the immune response to pathogens and thereby preventing damage to the host [20]. Recently, research has shown that IL-10 and related cytokines can facilitate the tissue-healing process in injuries caused by infection or inflammation [21]. According to these studies, mediators thought to be involved in the regulation of inflammation responses such as leukocyte recruitment, adhesion molecule expression, and wound healing in the late phase of inflammation.

\section{Inflammation and Cancer}

The inflammatory cells and cytokines present in tumors are more likely to contribute to tumor growth, progression, and immunosuppression than they are to induce an effective host antitumor response [22]. Inflammatory leukocytes such as neutrophils, monocytes, macrophages, and eosinophils provide the soluble factors that are thought to mediate the development of inflammationassociated cancer, although other cells, including the cancer cells, also participate [23]. In various forms of inflammation, the tumor microenvironment contains innate immune cells (including macrophages, neutrophils, mast cells, myeloid-derived suppressor cells, dendritic cells, and natural killer cells) and adaptive immune cells ( $\mathrm{T}$ and B lymphocytes) in addition to cancer cells and their surrounding stroma (which consist of fibroblasts, endothelial cells, pericytes, and mesenchymal cells) [24]. Previously published literature has indicated that the resulting activity of inflammatory mediators, such as cyclooxygenase (COX)-2, creates a tumor-promoting environment in which transformed epithelial cells [25] and COX-2 are inducible by oncogenes ras and scr, IL-1, hypoxia, ultraviolet light, epidermal growth factor, transforming growth factor beta, and TNF- $\alpha$ [26]. Studies have expanded on the concept that inflammation is a critical component of tumor progression, and many cancers arise from sites of infection, chronic irritation, and inflammation [27]. Investigation of the inflammatory substances involved in the process may help us prevent even cure the cancer disease.

\section{REFERENCES}

[1] P. Allavena, A. Sica, G. Solinas, et al., "The Inflammatory Micro-Environment in Tumor Progression: The
Role of Tumor-Associated Macrophages," Critical Reviews in Oncology/Hematology, Vol. 66, No. 1, 2008, pp. 1-9. http://dx.doi.org/10.1016/j.critrevonc.2007.07.004

[2] N. A. Punchard, C. J. Whelan and I. Adcock, "The Journal of Inflammation,” Journal of Inflammation, Vol. 1, No. 1, 2004, p. 1. http://dx.doi.org/10.1186/1476-9255-1-1

[3] D. Maslinska and M. Gajewski, "Some Aspects of the Inflammatory Process,” Folia Neuropathologica, Vol. 36, No. 4, 1998, pp. 199-204.

[4] I. Sbarsi, C. Falcone, C. Boiocchi, et al., "Inflammation and Atherosclerosis: The role of TNF and TNF Receptors Polymorphisms in Coronary Artery Disease," International Journal of Immunopathology and Pharmacology, Vol. 20, No. 1, 2007, pp. 145-154.

[5] P. Libby, P. M. Ridker and A. Maseri, "Inflammation and Atherosclerosis,” Circulation, Vol. 105, No. 9, 2002, pp. 1135-1143. http://dx.doi.org/10.1161/hc0902.104353

[6] J. M. Schott and T. Revesz, "Inflammation in Alzheime’s Disease: Insights from Immunotherapy,” Brain, Vol. 136, 2013, pp. 2654-2656. http://dx.doi.org/10.1093/brain/awt231

[7] J. M. Rubio-Perez and J. M. Morillas-Ruiz, "A Review: Inflammatory Process in Alzheimer's Disease, Role of Cytokines,” Scientific World Journal, Vol. 2012, 2012. Article ID: 756357 http://dx.doi.org/10.1100/2012/756357

[8] C. D. Gregory, "Inflammation and Cancer Revisited: An Hypothesis on the Oncogenic Potential of the Apoptotic Tumor Cell," Autoimmunity, Vol. 46, No. 5, 2013, pp. 312-316. http://dx.doi.org/10.3109/08916934.2012.755961

[9] B. B. Aggarwal, S. Shishodia, S. K. Sandur et al., "Inflammation and cancer: How Hot Is the Link?" Biochemical Pharmacology, Vol. 72, No. 11, 2006, pp. 16051621.

[10] G. S. Hotamisligil, N. S. Shargill and B. M. Spiegelman, "Adipose Expression of Tumor-Necrosis-Factor-AlphaDirect Role in Obesity-Linked Insulin Resistance," Science, Vol. 259, No. 5091, 1993, pp. 87-91. http://dx.doi.org/10.1126/science.7678183

[11] J. L. Dunne, R. G. Collins, A. L. Beaudet, et al., "Mac-1, but Not LFA-1, Uses Intercellular Adhesion Molecule-1 to Mediate Slow Leukocyte Rolling in TNF-AlphaInduced Inflammation,” Journal of Immunology, Vol. 171, No. 11, 2003, pp. 6105-6111.

[12] C. V. Carman and T. A. Springer, "A Transmigratory Cup in Leukocyte Diapedesis Both through Individual Vascular Endothelial Cells and between Them,” Journal of Cell Biology, Vol. 167, No. 2, 2004, pp. 377-388. http://dx.doi.org/10.1083/jcb.200404129

[13] S. K. Fried, D. A. Bunkin, and A. S. Greenberg, “Omental and Subcutaneous Adipose Tissues of Obese Subjects Release Interleukin-6: Depot Difference and Regulation by Glucocorticoid," Journal of Clinical Endocrinology \& Metabolism, vol. 83, No. 3, 1998, pp. 847-850. http://dx.doi.org/10.1210/jc.83.3.847

[14] Z. Xing, J. Gauldie, G. Cox, et al., “IL-6 Is an Antiinflammatory Cytokine Required for Controlling Local or 
Systemic Acute Inflammatory Responses,” Journal of Clinical Investigation, Vol. 101, No. 2, 1998, pp. 311-320. http://dx.doi.org/10.1172/JCI1368

[15] T. Sakurai, G. He, A. Matsuzawa, et al., "Hepatocyte Necrosis Induced by Oxidative Stress and IL-1 Alpha Release Mediate Carcinogen-Induced Compensatory Proliferation and Liver Tumorigenesis," Cancer Cell, Vol. 14, No. 2, 2008, pp. 156-165. http://dx.doi.org/10.1016/j.ccr.2008.06.016

[16] R. M. Gallucci, P. P. Simeonova, J. M. Matheson, et al., "Impaired Cutaneous Wound Healing in Interleukin-6Deficient and Immunosuppressed Mice,” Faseb Journal, Vol. 14, No. 15, 2000, pp. 2525-2531. http://dx.doi.org/10.1096/fj.00-0073com

[17] C. Gabay, C. Lamacchia and G. Palmer, "IL-1 Pathways in Inflammation and Human Diseases," Nature Reviews Rheumatology, Vol. 6, No. 4, 2010, pp. 232-241. http://dx.doi.org/10.1038/nrrheum.2010.4

[18] C. A. Dinarello, "Biologic Basis for Interleukin-1 in Disease,” Blood, Vol. 87, No. 6, 1996, pp. 2095-2147.

[19] G. E. Carpagnano, A. Spanevello, R. Sabato, et al., "Systemic and Airway Inflammation in Sleep Apnea and Obesity: The Role of ICAM-1 and IL-8," Translational Research, Vol. 155, No. 1, 2010, pp. 35-43. http://dx.doi.org/10.1016/j.trsl.2009.09.004

[20] M. Saraiva and A. O'Garra, "The Regulation of IL-10 Production by Immune Cells," Nature Reviews Immun- ology, Vol. 10, No. 3, 2010, pp. 170-181. http://dx.doi.org/10.1038/nri2711

[21] W. J. Ouyang, S. Rutz, N. K. Crellin, et al., "Regulation and Functions of the IL-10 Family of Cytokines in Inflammation and Disease," Annual Review of Immunology, Vol 29, 2011, pp. 71-109.

[22] F. Balkwill and A. Mantovani, "Inflammation and Cancer: Back to Virchow?” Lancet, Vol. 357, No. 9255, 2001, pp. 539-545. http://dx.doi.org/10.1016/S0140-6736(00)04046-0

[23] E. Shacter and S. A. Weitzman, "Chronic Inflammation and Cancer,” Oncology-New York, Vol. 16, No. 2, 2002, p. 217.

[24] S. I. Grivennikov, F. R. Greten and M. Karin, "Immunity, Inflammation, and Cancer," Cell, Vol. 140, No. 6, 2010, pp. 883-899. http://dx.doi.org/10.1016/j.cell.2010.01.025

[25] H. Clevers, "At the Crossroads of Inflammation and Cancer,” Cell, Vol. 118, No. 6, 2004, pp. 671-674. http://dx.doi.org/10.1016/j.cell.2004.09.005

[26] E. Fosslien, "Molecular Pathology of Cyclooxygenase-2 in Neoplasia," Annals of Clinical and Laboratory Science, Vol. 30, No. 1, 2000, pp. 3-21.

[27] L. M. Coussens and Z. Werb, "Inflammation and Cancer,” Nature, Vol. 420, No. 6917, 2002, pp. 860-867. 